\title{
Fannia flavicincta Stein (Diptera, Fanniidae): a new vector of Dermatobia hominis (Linnaeus Jr.) (Diptera, Cuterebridae)
}

\author{
Cleber Barreto Espindola ${ }^{1} \&$ Márcia Souto Couri ${ }^{1,2}$
}

\author{
${ }^{1}$ Departamento de Entomologia, Museu Nacional. Quinta da Boa Vista, 20940-040 Rio de Janeiro, Brasil. \\ ${ }^{2}$ Bolsista de Produtividade em Pesquisa, CNPq.
}

\begin{abstract}
Fannia flavicincta Stein, 1904 (Diptera, Fannidae) is first recorded as a vector of Dermatobia hominis (Linnaeus Jr., 1781). The material was collected in Paracambi, Rio de Janeiro, Brazil in September, 2002. KEY WORDS. Dermatobia eggs, first record.
\end{abstract}

RESUMO. Fannia flavicincta Stein, 1904 (Diptera, Fannidae) é registrada pela primeira vez como vetor de Dermatobia hominis (Linnaeus Jr., 1781). O material foi coletado em Paracambi, Rio de Janeiro, Brazil em setembro de 2002. PALAVRAS CHAVE. Ovos de Dermatobia, primeiro registro.

\begin{abstract}
Dermatobia hominis (Linnaeus Jr., 1781) (Diptera, Cuterebridae) has a very peculiar life cycle. The adults do not feed and after copulating, they catch another arthropod, in general hematophagous, and deposit their eggs near the root of the vector's wings or on its abdomen (Guimarães \& PAPAVERo 1999). As $D$. hominis is primarily a forest insect, its reproductive strategy is very peculiar. The females capture other insect species, mainly the blood feeders, using them as vectors while they could stay safety in the vegetation. When the vector land on a warm-blooded animal, the larvae emerge and penetrate the skin. The larval development complete in 30 or 40 days, and after this period the larvae abandon the host to pupate in soil. The pupae last about 30 or 60 days during the hot time, and 120 days during the cold time (Guimarães \& Papavero 1999, MarCondes 2001).

The production of meat, milk and leather from cattle in the neotropics is severely affected by infestations with $D$. hominis larvae, the economic damage caused by this parasite to the cattle industry in Brazil and Central America is enormous, losses being estimated at US\$200 million per year (Rodrigues et al. 1999). According to Mateus (1977) apud GuimaRães \& PAPAVERo (1999), these damages are not well estimated in the tropics, and can reach US\$260 million. MuLLISON \& SHEAver (1960) apud Guimarães \& Papavero (1999) furnished the following estimated annual losses in Central America: US\$ 450 million in the production of milk, US\$ 3,25 million in the meat and US\$ 1 million in leather and hides.
\end{abstract}

The list of vectors of $D$. hominis eggs presented by Guimarães \& Papavero (1999) include 53 arthropods, 98,1\% being dipterans (Tab. I).

The family Fanniidae has five identified species recorded as D. hominis vectors: Fannia heydenii (Wiedemann, 1830); Fannia pennicillaris (Stein, 1900); Fannia petrocchiae Shannon \& Del
Ponte, 1926; Fannia punctipennis Albuquerque, 1954; Fannia scalaris (Fabricius, 1794); one Fannia sp., and one Faniidae not identified (Guimarães \& Papavero 1999).

The common habit of adults Fannia Robineau-Desvoidy, 1830 is to hover outdoors near low branches of trees or more rarely, in the open. These small swarms are usually mostly males; the females are found in the lower vegetation, and can be collected by sweeping (СнiLlсотт 1960).

Understanding the epidemiology of dermatobiasis in the Neotropics depends on the knowledge of the biology, ecology and ethology of the vectors implicated in the transmission of the parasite in a particular region (Rodrigues et al. 1999). This is why the discovery of a new vector is important.

During fieldworks studing the structure and dynamics population of the muscoids in three different areas of the municipal district of Paracambi, Rio de Janeiro, a new vector of $D$. hominis eggs was founded.

\section{MATERIAL AND METHODS}

The harvests were made from September 2001 to August 2002 , in Paracambi city $\left(179,8 \mathrm{~km}^{2}\right.$ and 40.412 inhabitants Iвge 2000), located at $22^{\circ} 36^{\prime} 49^{\prime \prime} \mathrm{S}$ and $43^{\circ} 42^{\prime} 33^{\prime \prime} \mathrm{W}$ with medium altitude of 50 meters. Approximately $22,3 \%$ of its territory is covered by Atlantic forest, $17,2 \%$ by secondary vegetation, 2,4\% of agricultural area and 1,9\% of urban area (CIDE 2000). The temperatures in the lowland can reach $40^{\circ} \mathrm{C}$ or a bit over in the summer, while in the highest areas they can fall to $6^{\circ} \mathrm{C}$; the annual rainfall is about $1.224,9 \mathrm{~mm}$, the largest values occurring during the hottest months; the monthly averages vary from $195 \mathrm{~mm}$ in January to $30,7 \mathrm{~mm}$ in July (Experimental Station of Itaguaí/PESAGRO-Rio; $22^{\circ} 45^{\prime} S$ and $\left.43^{\circ} 41^{\prime} \mathrm{W}, 33 \mathrm{~m}\right)$.

Revista Brasileira de Zoologia 21 (1): 115-116, março 2004 

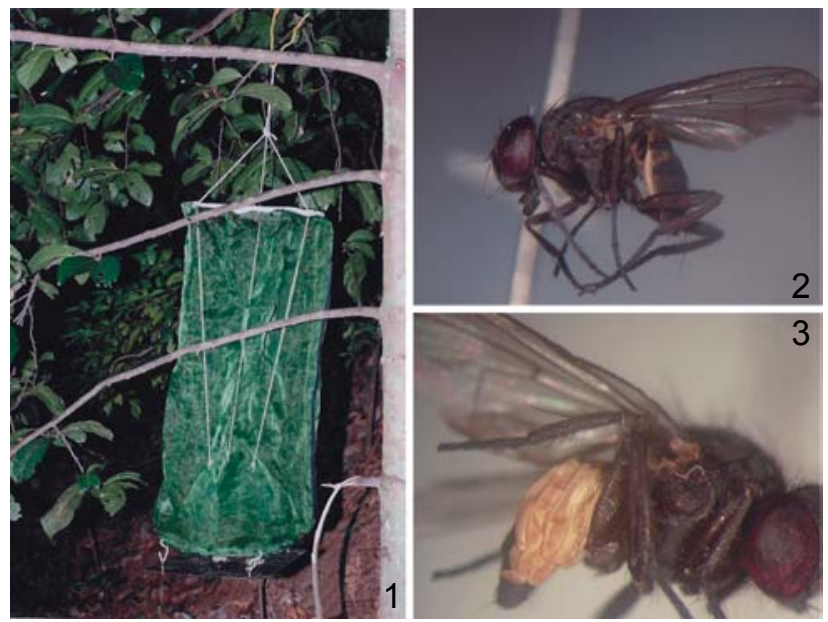

Figures 1-3. (1) Trap used to collect adults of Fannia sp.; (2) Fannia flavicincta with Dermatobia hominis eggs on ventral surface of the abdomen; (3) Fannia flavicincta with Dermatobia hominis eggs on lateral surface of the abdomen.

For harvest, baits were deposited on the acrilic base of nylon traps having $80 \mathrm{~cm}$ in length and $30 \mathrm{~cm}$ in diameter (Fig. 1). The traps were placed a meter above the ground in three different areas of the town: forest, rural and urban area. The traps were settled during five consecutive days at the first week of each month and harvest were done daily. Sardine previously left for 48 hours in environment for decomposition was used as bait.

\section{RESULTS}

During the harvests realized in the forest area ( $\mathrm{S} 22^{\text {nd }}$ $35^{\prime} 872^{\prime \prime}$ ', WO $43^{\text {rd }} 42^{\prime} 349^{\prime \prime}, 125,4 \mathrm{~m}$ ) on September 13 , seven males and 143 females of Fannia flavicincta Stein, 1904 were captured. Five females carried eggs of $D$. hominis in the inferior area of the abdomen (Figs 2 and 3), three females had eggs on the right side of the abdomen (12, 10 and four eggs respectively) and two on the left side (four and 10 eggs respectively).

The temperature at that day ranged from $27,7^{\circ} \mathrm{C}$ to $16,8^{\circ} \mathrm{C}$, the medium being $22,5^{\circ} \mathrm{C}$. The relative humidity of the air was $49 \%$. In the previous day of this collection, it rained weakly $(4,8 \mathrm{~mm}$ in an hour and fifty minutes).

BRITO \& BORJA (2000), in a study of the seasonal fluctuation of $D$. hominis in bovine skins from the slaughterhouse, showed
Table I. List of arthropods families vectors of Dermatobia hominis eggs.

\begin{tabular}{cc}
\hline \multicolumn{1}{c}{ Vector } & Number of species \\
\hline Diptera & 24 \\
Culicidae & 2 \\
Simulidae & 1 \\
Tabanidae & 1 \\
Antomyiidae & 11 \\
Muscidae & 2 \\
Sarcophagidae & 5 \\
Calliphoridae & 6 \\
Fanniidae & \\
Acari & 1 \\
Ixodidae &
\end{tabular}

that the increase of parasited skins was correlated with the increase of both temperature $\left(25^{\circ} \mathrm{C}\right)$ and rain (above $200 \mathrm{~mm}^{3}$ ).

\section{REFERENCES}

BRITO, L.G. \& G.E.M. BorJA. 2000. Flutuação populacional de Dermatobia hominis em peles bovinas oriundas de matadouro. Pesquisa Veterinária Brasileira, Rio de Janeiro, 20 (4): 151-154.

Cide (Centro de Informações e Dados do Rio de Janeiro). 2000. Anuário Estatístico do Estado do Rio de Janeiro, Rio de Janeiro, 16: 1-589.

Chillcott, J.G. 1960. A revision of the Neartic species of Fannia (Diptera: Muscidae). The Canadian Entomologist, Ontario, 14, 295p.

Guimarães, J.H. \& N. Papavero. 1999. Myiasis and animals in the Neotropical region: bibliographic database. São Paulo, Ed. Plêidade, FAPESP, 308p.

IBGE (Instituto Brasileiro de Geografia e Estatística). 2000. Censo Demográfico 2000. Características da população e dos domicílios. Rio de Janeiro, IBGE, 520p.

Marcondes, C.B. 2001. Entomologia Médica e Veterinária. São Paulo, Ed. Atheneu, Série Otoneurológica, 432p.

Rodrigues, Z.; R.C. Leite \& P.R. Oliveira. 1999. Ophyra aenescens (L.) (Diptera: Muscidae) a new biological vector of Dermatobia hominis (L. Jr.) (Diptera: Cuterebridae) in Minas Gerais, Brazil. Memórias do Instituto Oswaldo Cruz, Rio de Janeiro, 94 (1): 53-54.

Received in 29.VIII.2003; accepted in 28.I.2004. 